DOI:10.31933/DIJEMSS

Received: $26^{\text {th }}$ August 2020, Revised: $14^{\text {th }}$ September 2020, Publish: $18^{\text {th }}$ October 2020

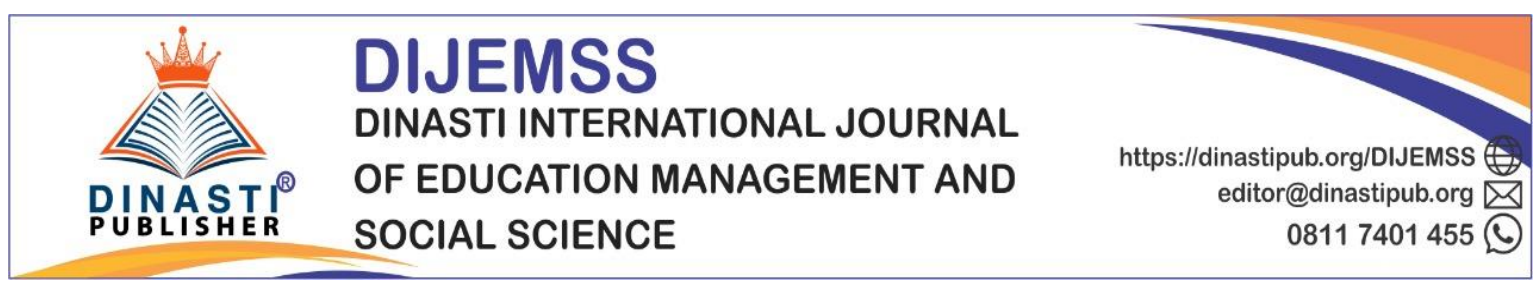

\title{
THE INFLUENCE FROM FINANCIAL PERFORMANCE ON EARNING PER SHARE (EPS) WITH SOUNDNESS LEVEL OF BANKS AS INTERVENING VARIABLE AT BUKU IV BANKS CATEGORY IN INDONESIA
}

\author{
Rosmery Thomas ${ }^{1}$, Selamet Riyadi ${ }^{2}$, Zaenal Abidin ${ }^{3}$, Muhammad Iqbal ${ }^{4}$ \\ 1) Perbanas Institute, Jakarta, Indonesia, rose081005@yahoo.com \\ 2) Perbanas Institute, Jakarta, Indonesia \\ ${ }^{3)}$ Perbanas Institute, Jakarta, Indonesia \\ 4) Perbanas Institute, Jakarta, Indonesia
}

\section{Corresponding Author: Rosmery Thomas}

\begin{abstract}
The purpose of this research was to analyze those influence of financial ratios towards earnings per share with soundness level of banks as an intervening variable based on risk-based bank rating method at BUKU IV Banks in Indonesia for the period of 2015-2019. The six banks are PT Bank Mandiri Tbk, PT Bank Rakyat Indonesia Tbk, PT Bank Negara Indonesia Tbk, PT Bank Central Asia Tbk, PT Bank CIMB Niaga Tbk and PT Bank Danamon Indonesia Tbk. This research used secondary data with quantitative approach. Data analysis technique used panel data regression by purposive sampling. The results showed that NPL \& GCG had significant negative influence on soundness level of banks and NPL had significant negative impact on EPS. GCG had significant positive influence against EPS, and ROA \& CAR did not have significant positive impact towards soundness level of banks \& EPS, while soundness level of banks were not found to have significant negative affect to EPS, and soundness level of banks did not mediate NPL, GCG, ROA and CAR in affecting EPS.
\end{abstract}

Keywords: Financial ratios, soundness level of banks, earning per share.

\section{INTRODUCTION}

The economic crisis which occurred in Asian countries including Indonesia has caused banking sector to experience downturn and difficult times that are marked by the depreciation of rupiah exchange rate against USD dollar, the tight liquidity which resulted in bank having difficulties in obtaining fresh fund and the increasing number of non-performing loans. With this condition, it has resulted in a crisis of customer's faith and the poor Interbank Money Market.

The case is not about the weakness of a bank's supervisory function, but a bank is a business entity which is fully obliged to maintain and protect national banking from various risks and supervision is much necessary. In the beginning, in the Bank Indonesia's regulations 
number 6/23/DPND, the grading system of bank soundness level utilized the CAMELS method; however on October 25th, 2011, the assessment system of bank soundness level was enhanced into Risk-Based Bank Rating (RBBR) method. The measurement of bank soundness level by modernized risk rating method, which consists of four factors, namely risk profile, good corporate governance (GCG), earnings and capital.

Those existence from this case proved that how important the role of banks and the strategic role in intermediation process which has a major impact on the economy. These require the banking sector to improve its good performance, where all existing banks guarantee the safety of public's money, not only to build public trust but also to attract more people to become customers of these banks. Beside that, Bank had the responsibility to improve and maintain its performance in any condition. Banks were also required to maintain and retain the soundness level of banks by applying the prudent principle and risk management in carrying out bank business activities with the provisions of capital adequacy, asset quality, management quality, liquidity, profitability and solvency.

In order to increase public confidence in management of financial business, it is necessary to carry out an assessment and measurement over the soundness level of banks. One of the sources that could be used as a benchmark in evaluating the condition of a bank's soundness level and financial performance is through the bank's financial report. The function of using Financial Statement is to find out the condition or financial position of a bank during that time or in a certain period. Then the results from its financial statement analysis used as an information to the financial report users regarding the strengths and weaknesses of a bank as basis for decision making.

This research was carried out and focused on the four assessment factors, which are Risk Profile, Good Corporate Governance (GCG), Earnings and Capital. Risk Profile is an assessment from internal risk factors and quality of representation from risk management in bank operations with 8 (eight) risks which including credit risk, operational, market, legal, liquidity, strategic, compliance, and reputational (Financial Services Authority Regulation Number 18/PJOK.03/2016). There are several risks, but only use the credit risk in soundness level of calculation which measured by Non-Performing Loan (NPL) ratio.

Previous research that conducted by Lasta (2014) found if performance from PT Bank Rakyat Indonesia Tbk in 2011-2013 using RGEC Method (Risk Profile, Good Corporate Governance, Earning, Capital) showed a good soundness of bank level in activities, such as capital, risk profile and profitability. Meanwhile, according to Ramadhany (2015) the soundness level of state owned banks were was better than national private of foreign exchange banks because the average value of ROA, NIM and CAR from state owned banks were higher even though the average from NPL and LDR values of national private of foreign exchange banks were smaller compared to state owned banks.

Amilia Paramita Sari's research (2018) showed that GCG had significant positive impact towards soundness level of banks, but ROA had none effect to soundness level of banks. While, Ardiani research (2007) showed that ROA had significant positive influence towards stock prices, CAR did not have significant influence on stock prices. According to Mega Santiti in Riyadi (2014), NPL had significant positive impact over stock prices. Meanwhile, Nurhartanto (2010) defined that CAR, EPS, NPL, LDR had significant positive influence towards stock prices.

According to Praditasari (2009) the soundness level of banks (CAMEL) had significant influence towards stock prices using variables (NPL, LDR, CAR). Meanwhile, Purwasih (2010) was examined that soundness level of banks (CAMEL) by variables (CAR and LDR) which had not significant influence towards stock prices. Research by Cheung el al in Tjondro 
and Wilopo (2011) showed that GCG had significant influence on company value. Meanwhile, Sakai and Asaoka in Tjondro and Wilopo (2011) had observed that GCG had significant positive influence towards PER.

Based on the expansion from the background and the tendency of influence between bank's performance and the soundness level of banks towards Earning Per Share (EPS), therefore, the researcher conducted this research which was focused on the six Commercial Banks at Bank BUKU IV (PT. Bank Mandiri Tbk, PT Bank Rakyat Indonesia Tbk, PT Bank Negara Indonesia Tbk, PT Bank Central Asia Tbk, PT Bank CIMB Niaga Tbk and PT Bank Danamon Indonesia Tbk) with core capital of at least 30 trillion rupiah.

\section{THEORETICAL REVIEW}

\section{Risk Profile}

Risk Profile is an assessment from internal risk factors and implemented of risk management quality in bank operationals with 8 (eight) risks namely credit risk, operational, market, legal, liquidity, strategic, compliance and reputational (Financial Services Authority Regulation Number 18/POJK.03/2016). There are several risks, but only use the credit risk in soundness level of calculation which measured by Non-Performing Loan (NPL) ratio.

\section{Good Corporate Governance (GCG)}

Good Corporate Governance (GCG) is an assessment factor of internal management performance with a self-assessment system by calculating the GCG component. Based on Bank Indonesia Regulation No.13/1/PBI/2011 and Bank Indonesia Circular Letter (SEBI) Number 15/15/DPNP of 2013, banks carry out their own GCG assessment based on a self-assessment system on a regular basis by searching for annual reports published for the determination of GCG assessment. GCG assessment consists of three aspects, which are Governance Structure, Governance Process and Governance Outcomes.

\section{Rentability}

Rentability (Earnings) that could be carried out by using Return on Assets (ROA) and Earning Per Share (EPS) ratios. Return on Assets (ROA) is a ratio to measure about bank's capability to generate profits and manage the bank's overall business efficiency level. Meanwhile, Earnings Per Share (EPS) used to compare the available or generated income (net income) to the number of outstanding shares at the end of period.

\section{Capital}

Capital could be measured by Capital Adequacy Ratio (CAR). According to Dendawijaya (2009:121) and Irawan and Syarif (2019), Capital Adequacy Ratio (CAR) is a ratio which showed that how far all bank assets had contained risk (loans, investments, securities, claims at other banks) were also funded from bank capital itself, besides to obtain funds from the sources outside the bank, such as community funds, loans and others.

\section{Theoretical Framework}

Based on these descriptions and explanations which had been done above, this research was formed because of interdependence between variables which considered important to be studied. These research model based on theoretical framework could be seen in the image as below. 


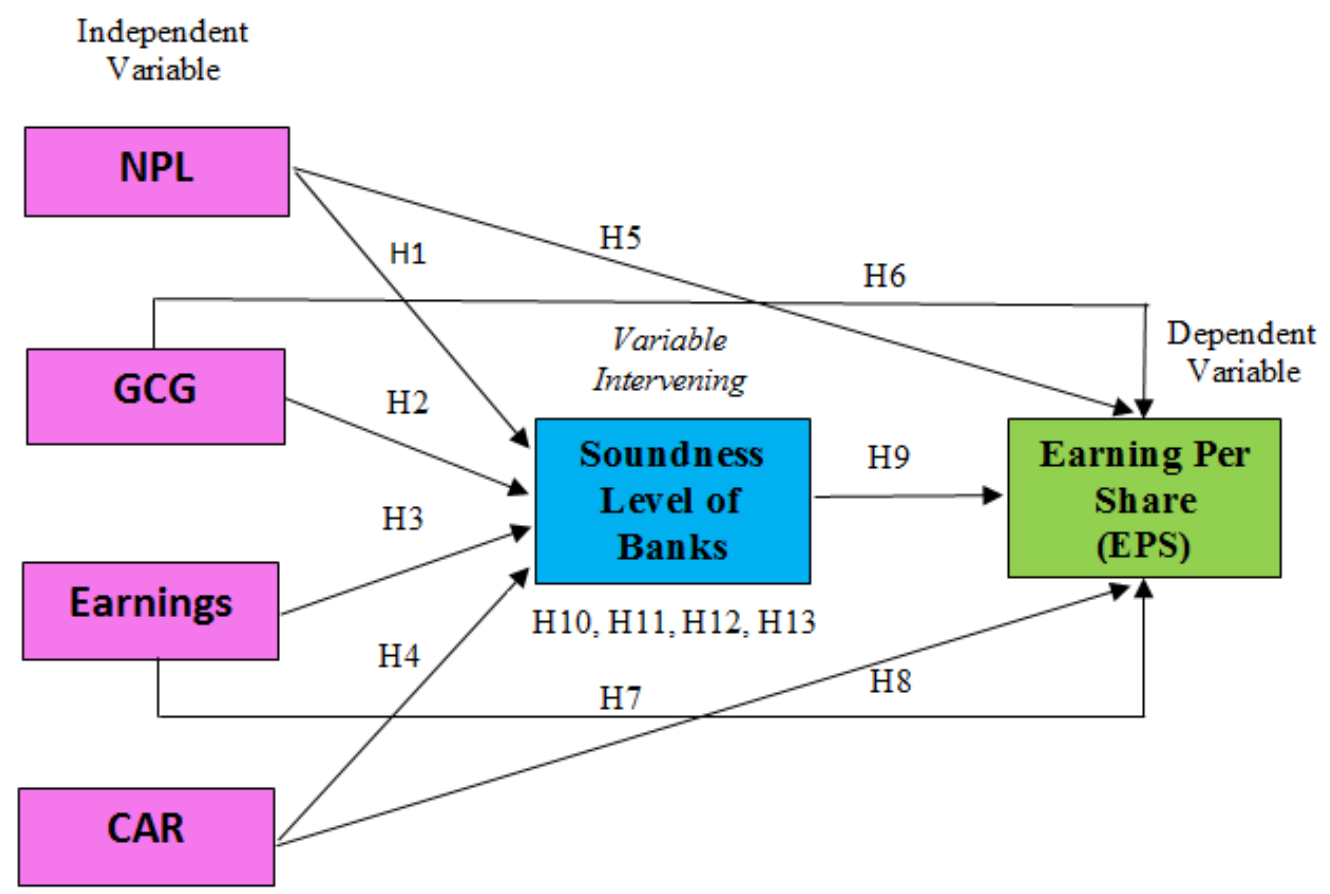

Figure 1. Theoretical Review

\section{Hypothesis}

The hypothesis in this research were 1) Non Performing Loans (NPL) had an influence toward Soundness Level of Banks; 2) Good Corporate Governance (GCG) had an affect to the Soundness Level of Banks ; 3) Earnings had influence towards the Soundness Level of Banks, 4) Capital Adequacy Ratio (CAR) had an affect the Soundness Level of Banks ; 5) Non Performing Loan (NPL) had influence towards Earning Per Share (EPS); 6) Good Corporate Governance (GCG) affects Earning Per Share (EPS); 7) Earnings had impact to Earning Per Share (EPS); 8) Capital Adequacy Ratio (CAR) affects those Earning Per Share (EPS); 9) Soundness Level of Banks had influence towards Earning Per Share (EPS); 10) Soundness Level of Banks had contribution in mediation Non Performing Loans (NPL) in affecting to Earning Per Share (EPS); 11) Soundness Level of Banks had contribution in mediation Good Corporate Governance (GCG) in affecting to Earning Per Share (EPS); 12) Soundness Level of Banks had contribution in mediation Earnings in affecting to to Earning Per Share (EPS); and 13) Soundness Level of Banks had contribution in mediation Capital Adequacy Ratio (CAR) in affecting to Earning Per Share (EPS).

\section{RESEACH METHODS}

This research theoretically aims to examine those influence from bank's financial performance on soundness level of banks and its impact to bank's earning per share by mathematical model approach and hypothesis test as a way of testing. These independent variables in this research were Non Performing Loans (NPL), Good Corporate Governance (GCG), Earnings (Profitability) using ROA (Return on Assets) as a parameter, and Capital Adequacy Ratio (CAR). The intervening variable in this research was the soundness level of Banks. The dependent variable in this research was Earning Per Share (EPS). These population and sample were Commercial Bank from BUKU IV Category which consisted of six banks, namely PT Bank Mandiri (Persero) Tbk, PT Bank Rakyat Indonesia (Persero) Tbk, PT Bank Negara Indonesia (Persero) Tbk, PT Bank Central Asia Tbk, PT. Bank CIMB Niaga Tbk and 
PT Bank Danamon Indonesia Tbk for the period of 2015-2019. The sample selection used purposive sampling method and sample selection based on predetermined criteria. This research used secondary data with quantitative approach. In accordance to research objectives that would be analyzed to those impact from independent variables towards dependent variable with the help of intervening variables, path analysis methods were used and data analysis techniques used panel data regression.

\section{RESULT AND DISCUSSION}

\section{Statistical Description of Research Variables}

From these research results, it is known that average NPL ratio was $2.54 \%$, this had indicated that NPL value was still within the specified maximum NPL limit stipulated by Bank Indonesia. The average GCG ratio was $1.7 \%$, this means that Bank was carried out of its own GCG (self-assessment) routinely. The average ROA ratio was $2.88 \%$ with maximum ratio was $4.20 \%$ and minimum ratio was $0.47 \%$ with standard deviation of $0.93 \%$. CAR from BUKU IV Bank showed that these average ratio was $20.80 \%$ with maximum ratio was $24.20 \%$ and minimum ratio was $16.28 \%$ with standard deviation of $1.96 \%$, this means that CAR met the requirements which stipulated by Bank Indonesia (at least $8 \%$ ). The average from BUKU IV bank's soundness level of banks ratio showed $88.34 \%$ with maximum ratio was $96.67 \%$ and minimum ratio was $76.67 \%$ by standard deviation of $4.61 \%$. The average Earnings Per Share (EPS) ratio from BUKU IV bank showed that 535\% with maximum ratio was $1.159 \%$ and a minimum ratio was $34.00 \%$ with standard deviation of $334 \%$.

Table 1. Descriptive Statistics from Research Variables

\begin{tabular}{lrrrrrr}
\hline \hline & NPL & GCG & ROA & CAR & EPS & \multicolumn{1}{c}{ TK } \\
\hline Mean & 2.541667 & 1.700000 & 2.876667 & 20.79133 & 535.3667 & 88.33600 \\
Median & 2.660000 & 2.000000 & 3.015000 & 21.08500 & 464.5000 & 86.67000 \\
Maximum & 3.960000 & 2.000000 & 4.190000 & 24.20000 & 1159.000 & 96.67000 \\
Minimum & 0.700000 & 1.000000 & 0.470000 & 16.28000 & 34.00000 & 76.67000 \\
Std. Dev. & 0.817381 & 0.466092 & 0.931999 & 1.967385 & 333.7063 & 4.611331 \\
Skewness & -0.203364 & -0.872872 & -0.623656 & -0.220242 & 0.293124 & 0.238591 \\
Kurtosis & 2.563964 & 1.761905 & 2.824511 & 2.292289 & 1.852222 & 3.758942 \\
Jarque-Bera & 0.444445 & 5.725624 & 1.983227 & 0.868602 & 2.076351 & 1.004620 \\
Probability & 0.800737 & 0.057108 & 0.370978 & 0.647717 & 0.354100 & 0.605131 \\
Sum & 76.25000 & 51.00000 & 86.30000 & 623.7400 & 16061.00 & 2650.080 \\
Sum Sq. Dev. & 19.37522 & 6.300000 & 25.19007 & 112.2475 & 3229437. & 616.6667 \\
Observations & 30 & 30 & 30 & 30 & 30 & 30 \\
\hline \hline
\end{tabular}

Source: Output of EViews-10 (2020)

\section{Panel Data Regression Model Selection}

Based on the output results from the F Cross-section Probability Value from models I \& II, there were differences. The Cross-section F probability value from model I was 0.0014 while the Cross-section F probability value from model II showed zero where both probability values were less than 0.05 alpha so that it could be concluded that the null hypothesis from the Chow test results (model from the common effect were more precise than the fixed effect model) was rejected. The conclusion means that the fixed effect model which more appropriate to explain those impact from independent variables towards the dependent variable compared to $\mathrm{CE}$ model. Since the FE is the most appropriate model, the next step is to perform the Hausman test. 
Table 2. Chow Test

\begin{tabular}{llrl}
\hline \hline Model & Effects Test & Statistic & Prob. \\
\hline \hline Model I & Cross-section F & 6.080 .163 & 0.0014 \\
Model II & Cross-section F & 11.494 .979 & 0.0000 \\
\hline \hline
\end{tabular}

Source: Output of EViews-10 (2020)

The results from Hausman Model I and Model II tests had different values, however the two random cross-section probability values for model I were greater than alpha 0.05 , so the null hypothesis from the Hausman test (RE model was more precise than FE model) for model I accepted. Meanwhile, these results from model II test showed these probability value from random cross-section 1, meaning that RE model was not precise so the FE model was chosen to explain these model II equation. From these model selection result, it could be seen that the model which used for path analysis was RE for model I and FE for model II. In the future, RE model I and FE model II will be used to examine those research hypothesis as well as explain those impact from independent variable (exogenous) towards dependent variable (endogenous).

Table 3. Hausman Test

\begin{tabular}{llrc}
\hline \hline Model & Test Summary & Chi-Sq. Statistic & Prob. \\
\hline \hline Model I & Cross-section random & 3.229 .600 & 0.5202 \\
Model II & Cross-section random & 0.000000 & 1.0000 \\
\hline \hline
\end{tabular}

Source: Output of EViews-10 (2020)

\section{Multicollinearity and Normality Assumption Test}

Based on these data output from multicollinearity test, it could be explained that the correlation between independent variable of NPL and GCG did not contain a value that close to number 1 , even it tends to be small below 0.4 , only CAR with value of 0.6 . This proved that the correlation between independent variables was weak so it could be said that there were no multicollinearity symptom. Which means that multicollinearity assumption was fulfilled.

Table 4. Multicollinearity Test

\begin{tabular}{|c|c|c|c|c|}
\hline & NPL & GCG & ROA & CAR \\
\hline NPL & 1 & - & - & - \\
\hline GCG & 0.35707 & 1 & - & - \\
\hline ROA & -0.81440 & -0.37150 & 1 & - \\
\hline CAR & -0.33477 & -0.34326 & 0.64826 & 1 \\
\hline
\end{tabular}

Source: Output of EViews-10 (2020)

Based on output results, it showed that the Jaque-Bera Test statistics for models I and II both exceeded 0.05 and this showed that these results from residual normality test in both models were declared normally distributed so the normality assumption was fulfilled.

Table 5. Residual Normality Test

\begin{tabular}{llrc}
\hline \hline Model & Types of Normality Test & JB. Statistic & Prob. \\
\hline \hline Model I & Jarque-Bera & 0.304852 & 0.858622 \\
Model II & Jarque-Bera & 0.375485 & 0.828828 \\
\hline \hline
\end{tabular}

Source: Output of EViews-10 (2020) 


\section{Model Feasibility Test}

Based on the results of panel data regression, random effect for model I and fixed effect for model II, the feasibility test from model was measured from the F test smaller than the error rate (alpha) 0.05 so both models were declared fit to use and to explain those impact from independent variable towards dependent variable. This means that these path analysis model formed could be explain those influence from independent variable towards dependent variable.

Table 6. F Test

\begin{tabular}{llcc}
\hline \hline Model & Model Panel Data & F-Statistic & Prob. \\
\hline \hline Model I & Random Effect & 4.538 .018 & 0.00000 \\
Model II & Fixed Effect & 1.766 .808 & 0.00001 \\
\hline \hline
\end{tabular}

Source: Output of EViews-10 (2020)

\section{Hypothesis Examination}

These regression equation from path analysis model could be formulated as follows:

$\mathrm{TK}=-0,3700 \mathrm{NPL}-0,5272 \mathrm{GCG}+0,1299 \mathrm{ROA}+0,1530 \mathrm{CAR}+\varepsilon_{1}$

$\mathrm{EPS}=-0,2420 \mathrm{NPL}+0,03745 \mathrm{GCG}+0,2880 \mathrm{ROA}+0,0740 \mathrm{CAR}-0,1710 \mathrm{TK}+\varepsilon_{2}$

Table 7. Path Analysis Model

\begin{tabular}{cccrrl}
\hline \hline Exogent Variable & & Endogent Variable & Std. Coefficient & t-Statistic & \multicolumn{1}{c}{ Prob. } \\
\hline NPL & $\rightarrow$ & TK & -0.369629 & -2.228 .997 & 0.0350 \\
GCG & $\rightarrow$ & TK & -0.527169 & -4.653 .206 & 0.0001 \\
ROA & $\rightarrow$ & TK & 0.129881 & 0.647773 & 0.5230 \\
CAR & $\rightarrow$ & TK & 0.153082 & 1.322 .808 & 0.1979 \\
NPL & $\rightarrow$ & EPS & -0.242025 & -2.301 .830 & 0.0328 \\
GCG & $\rightarrow$ & EPS & 0.374489 & 3.982 .029 & 0.0008 \\
ROA & $\rightarrow$ & EPS & 0.287976 & 2.063 .482 & 0.0530 \\
CAR & $\rightarrow$ & EPS & 0.073858 & 0.821181 & 0.4217 \\
TK & $\rightarrow$ & EPS & -0.170645 & -1.567 .808 & 0.1334 \\
\hline \hline
\end{tabular}

Source: Output of EViews-10 (2020)

Based on these results from direct influence test, it could be interpreted as follows:

1) The t-statistic probability value was 0.0350 , which is smaller than alpha 0.05 , so it could be explained that first hypothesis was accepted. Meaning that NPL had significant impact towards Soundness Level of Banks.

2) The t-statistic probability value was 0.0001 (less than 0.05 ) this was indicated that these second hypothesis was accepted, meaning that GCG had significant influence towards Soundness Level of Banks.

3) The t-statistic probability value was 0.5230 (greater than 0.05 ) which indicated that the third hypothesis was rejected, meaning that ROA had no impact on Soundness Level of Banks.

4) The t-statistic probability value was 0.1979 , which greater than alpha 0.05 , so it could be explained that the fourth hypothesis was rejected. Meaning that CAR had no affect on Soundness Level of Banks. 
5) The t-statistic probability value was 0.0328 which smaller than alpha 0.05 , so it could be said that the fifth hypothesis is accepted, which means that NPL had significant influence over EPS.

6) T-statistic probability value was 0.0008 which smaller than alpha 0.05 , so it could be explained that the sixth hypothesis was accepted. This means that GCG had significant influence towards EPS.

7) The t-statistic probability value was 0.0530 which greater than alpha 0.05 so it could be explained that the seventh hypothesis was rejected, meaning that ROA had no effect on EPS.

8) The t-statistic probability value was 0.4217 which greater than alpha 0.05 , so it could be explained that these eighth hypothesis was rejected, which means that CAR had no influence towards EPS.

9) The t-statistic probability value was 0.1134 which greater than alpha 0.05 , so it could be explained that these ninth hypothesis was rejected, meaning that Soundness Level of Banks had no effect towards EPS.

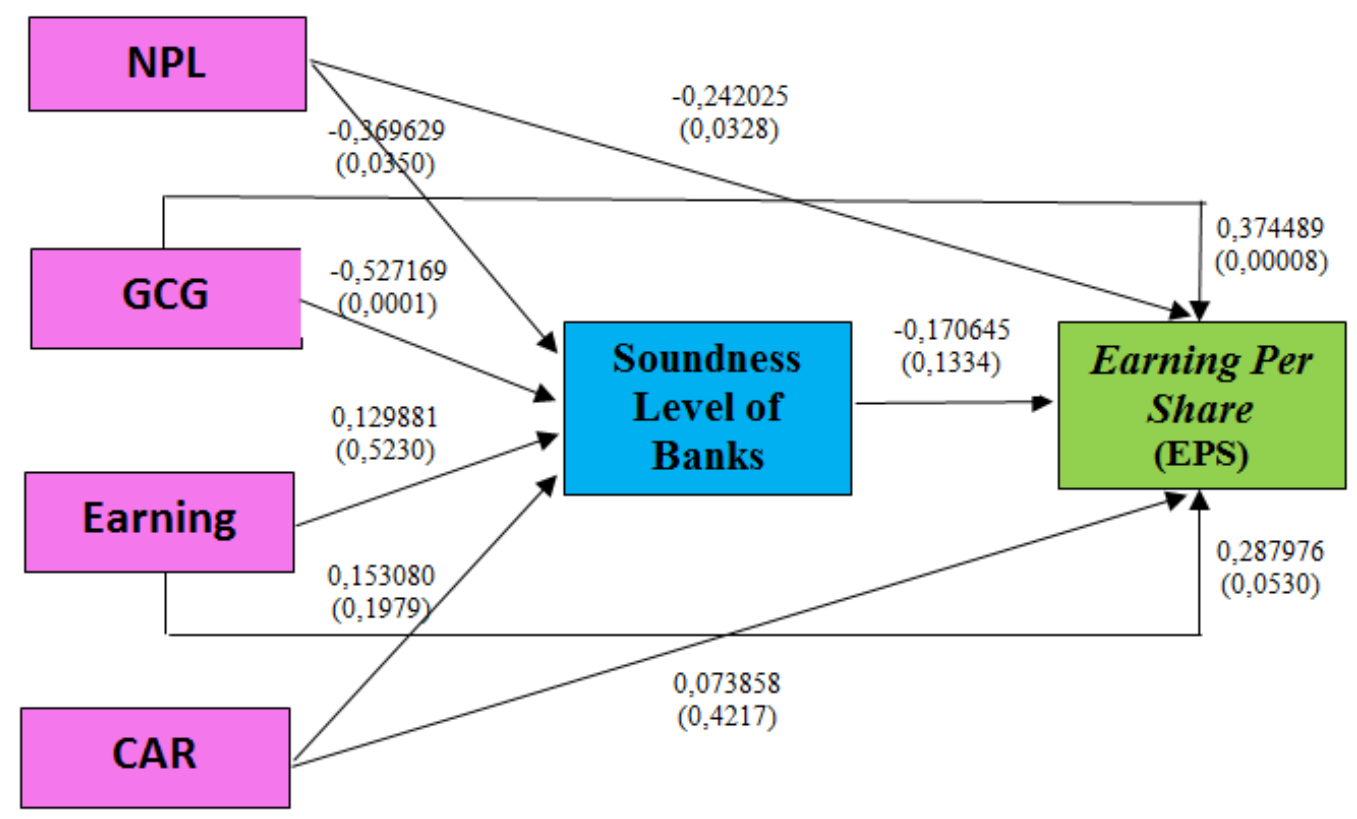

Figure 2. Path Analysis Chart

There were five exogeneous variables, where four of them only act as exogeneous variables (stated as independent variables), while another one has double roles as endogent variables as well (referred as intervening variables). Based on these indirect effect test result, it was shown that:

1) The direct effect from NPL on EPS was -0.2420 while these indirect effect was 0.0630 . Because these direct effect was greater than indirect effect (regardless of the negative sign), Soundness Level of Banks had not functioned well as an intervening variable. Meaning that the tenth hypothesis of this research was rejected, so Soundness Level of Banks did not have contribution in mediation NPL in affecting EPS.

2) The direct effect from GCG towards EPS was 0.3745 while the indirect effect had 0.0899 . Because these direct effect was greater than indirect effect one, so Soundness Level of Banks had not functioned well as an intervening variable. Meaning that the eleventh 
hypothesis from this research were rejected so Soundness Level of Banks did not have contribution in mediation GCG in affecting EPS.

3) Direct effect from ROA to EPS was 0.2880 while indirect effect was -0.0221 . Because these direct effect was greater than the indirect one, so Soundness Level of Banks had not functioned well as an intervening variable. Meaning that the twelveth hypothesis from this research was rejected, so Soundness Level of Banks did not have contribution in mediation ROA in affecting EPS.

4) Direct effect from CAR on EPS was 0.0739 while the indirect effect was -0.0261 . Because these direct effect was greater than indirect effect, so Soundness Level of Banks had not functioned well as an intervening variable. Meaning that these thirteenth hypothesis from this research was rejected, therefore Soundness Level of Banks did not have contribution in mediation CAR in affecting EPS.

Table 8. Indirect Effect

\begin{tabular}{ccccc}
\hline \hline Variable & NPL & GCG & ROA & CAR \\
\hline \hline EPS & 0.063075 & 0.089959 & -0.022164 & -0.026123 \\
\hline \hline \multicolumn{5}{c}{ Source: Output of EViews-10 (2020) } \\
\hline
\end{tabular}

\section{Discussion}

1) Test results from first hypothesis showed that NPL had significant influence towards Soundness Level of Banks with negative regression coefficient, so NPL had significant negative influence towards Soundness Level of Banks. This means that an increase in NPL ratio will decrease the value of Soundness Level of Banks and conversely.

2) Test results from second hypothesis showed that GCG had significant influence towards Soundness Level of Banks with negative regression coefficient, so GCG had significant negative impact towards Soundness Level of Banks. This means that an increased or decreased in the value of GCG had none influence to Soundness Level of Banks.

3) Test result from third hypothesis was indicated that ROA had no significant influence on Soundness Level of Banks with positive regression coefficient, so ROA had no significant positive influence on Soundness Level of Banks. This means that an increased or decreased in ROA value did not have positive impact towards Soundness Level of Banks.

4) Test result from fourth hypothesis shows that CAR had none significant positive influence towards Soundness Level of Banks. This means that an increased or decreased in CAR value did not have positive impact on Soundness Level of Banks.

5) Test results from fifth hypothesis showed that NPL had significant impact on EPS with negative regression coefficient, so NPL had significant negative influence on EPS.

6) Test results from sixth hypothesis showed that GCG had significant impact on EPS with positive regression coefficient, so GCG had significant positive effect towards EPS. Meaning that increased in the value of GCG will result in increase on value of EPS and conversely.

7) Test result from seventh hypothesis showed that ROA had no significant impact towards EPS with positive regression coefficient (table 4.12), so ROA had no significant positive impact towards EPS. Meaning that an increased or decreased in ROA value did not have positive impact towards EPS.

8) Test results from eighth hypothesis showed that CAR did not have significant impact to EPS with positive regression coefficient, so CAR did not have significant positive impact towards EPS. Meaning that an increase or decrease in CAR value did not have positive impact against EPS. 
9) Test results from ninth hypothesis showed that Soundness Level of Banks had no significant influence towards EPS with negative regression coefficient, so Soundness Level of Banks did not have significant negative impact to EPS.

10) Test results from tenth hypothesis showed that Soundness Level of Banks did not mediate NPL in affecting EPS. So there had none influence from Soundness Level of Banks in mediation that impact between NPL and EPS. This occurs because these direct relationship between NPL was significant and greater than indirect effect one, whereas Soundness Level of Banks as intervening factor, so the effect from NPL on EPS did not require the role of Soundness Level of Banks as intervening factor.

11) The test results from eleventh hypothesis shows that Soundness Level of Banks did not mediate GCG in affecting EPS. So there had no influence of Soundness Level of Banks in mediation on the effect of GCG and EPS. This happened because these direct relationship of GCG was significant and greater than indirect effect one, where Soundness Level of Banks as intervening factor, so the effect of GCG on EPS did not require the role of Soundness Level of Banks as intervening factor.

12) Test results from twelfth hypothesis showed that Soundness Level of Banks did not mediate ROA in affecting EPS. So there had no effect from Soundness Level of Banks in mediation that affect between ROA and EPS. This happened because direct relationship between ROA was significant and greater than indirect effect one, whereas Soundness Level of Banks as intervening factor, so those impact from ROA on EPS did not require Soundness Level of Banks as intervening factor.

13) Test results from thirteenth hypothesis showed that Soundness Level of Banks did not mediate CAR in affecting EPS. So there has no effect from Soundness Level of Banks in mediation that impact between CAR and EPS. This happened because these direct relationship of CAR was significant and greater than indirect effect one, whereas Soundness Level of Banks as intervening factor, so the effect from CAR on EPS did not require Soundness Level of Banks as intervening factor.

\section{CONCLUSION AND SUGGESTION Conclusion}

Based on these research results and those analysis from discussions which have been presented, it could be concluded from these thirteen hypothesis test results as described as follows: 1) NPL had significant negative impact on Soundness Level of Banks; 2) GCG had significant negative impact towards Soundness Level of Banks; 3) ROA had no significant positive effect on Soundness Level of Banks; 4) CAR had no significant positive impact towards Soundness Level of Banks; 5) NPL had significant negative effect on EPS; 6) GCG had significant positive effect on EPS; 7) ROA had no significant positive impact on EPS; 8) CAR did not have significant positive impact against EPS; 9) Soundness Level of Banks did not have significant negative effect on EPS; 10) Soundness Level of Banks did not mediate the NPL in affecting towards EPS; 11) Soundness Level of Banks did not mediate GCG in affecting towards EPS; 12) Soundness Level of Banks did not mediate ROA in affecting towards EPS; and 13) Soundness Level of Banks did not mediate CAR in affecting towards EPS. 


\section{Suggestion}

To contribute towards these research results, several recommendations could be presented as follows:

1) To anticipate the tendency of increasing Non Performing Loans (NPL) or the risk of nonperforming loans (default), banks should be more prudent and selective in providing and expanding credit in addition to taking steps for the non-performing loans settlement in order to reduce the cost of provision for non-performing loans, which in the end would lead to improvement in financial performance and soundness level of banks.

2) In implementing and evaluating the components of Good Corporate Governance (GCG), banks are obliged to complete the GCG Self-Assessment Working Paper by seeking an annual report that is published in order to determine the value of the composite rating from each criteria by comparing it with those indicators that has been stipulated by Bank Indonesia. Banks which successfully execute and implement the good corporate governance (GCG) properly would undoubtedly give a positive response towards consumer and investor, therefore the bank would obtain customers and increase the bank stock prices more easily. The better the implementation and the management of GCG at a bank, the better the bank's financial performance because the bank's goal could be achieved.

3) To increase profitability, banks should demonstrate the management capability of a bank in managing the level of overall bank performance effectiveness in order to obtain profits by utilizing its assets. Bank Indonesia has an assessment indicator which has been stipulated that good ROA ratio is above $1.5 \%$. The greater the ROA of bank, the better the bank's position in terms of asset usage. The bigger the level of ROA ratio would indicate that the bank has a large amount of profit, which would lead to larger amount of dividends being distributed to the shareholders.

4) In accordance with the regulation of Bank Indonesia which indicate the minimum CAR ratio level is $8 \%$ as the stipulated provisions mean that banks have to always strive to maintain the minimum CAR ratio to be the same or larger. If the CAR decrease, then the profitability would also decrease which leads to lower profitability. This issue could occur since bank has not been maximized in providing loans, ultimately resulting and driven the bank capital into a negative spread and the imbalance of increasing in assets with the addition of capital. The low CAR ratio level could lead to a decline in public's confidence which could conclusively lower profitability. When the value of Capital Adequacy Ratio (CAR) is relatively close to its minimum, then bank would need to have additional capital injection. Several ways to obtain the capital injection to increase the equity value of the bank which could be implemented through Right Issue and Initial Public Offering (IPO).

5) To increase the soundness level of banks, the assessment could be implemented using the calculation of financial ratios against those aspects and conditions of Financial Performance of a bank using RGEC method (Risk Profile, Good Corporate Governance, Earnings and Capital). In principle, the better the financial performance of a bank, the more profits and benefits it would give to shareholders, which could trigger an increase in stock prices.

6) In facing intense global competition, every bank, especially for those that have gone public, would definitely be required to have a good and reliable financial performance. The financial performance is not only in managerial terms, but also in financial terms. Bank financial performance is often used as the basis for consideration for investors in decisionmaking. One of them could be seen from Earning Per Share (EPS) factor. 


\section{REFERENCES}

Aris Fadjar, Hedwigis Esti R., Tri Prihatini E. (2013). "Analisis Faktor Internal Dan Eksternal Bank Yang Mempengaruhi Profitabilitas Bank Umum di Indonesia". Journal of Management and Business Review, 10(01), 63-77. htps://doi.org/10.36406/jam.v16i01.270.

Ardiani, A. (2007). Analisis Pengaruh Kinerja Keuangan Terhadap Perubahan Harga Saham Pada Perusahaan Perbankan di Bursa Efek Jakarta (BEJ). Skripsi. Fakultas Ekonomi Universitas Negeri Semarang, Semarang.

Bank Indonesia . (2011). Surat Edaran No.13/I/PBI/2011 tentang Penilaian Tingkat Kesehatan Bank Umum.

Bank Indonesia. (2013). Surat Edaran Nomor Nomor 15/15/DPNP tahun 2013 Perihal Pelaksanaan Good Corporate Governance Bagi Bank Umum.

Irawan, B. R., \& Syarif, A. D. (2019). Analysis the Effect of Fundamental Financial Ratio of CAR, LDR, LAR, Bank Size, OPE and NIM on Non-Performing Loans (NPL) of Banking Listed on the Indonesia Stock Exchange in 2012-2018. International Journal of Innovative Science and Research Technology, 4(10), 728-735.

Kasmir. (2014). Manajemen Perbankan. Jakarta: PT Raja Grafindo Persada.

Kasmir. (2015). Analisis Laporan Keuangan. Jakarta: PT Raja Grafindo Persada.

Laporan Tahunan Bank Mandiri (2015-2019). Terpublikasikan melalui website: https://www.bankmandiri.co.id/web/ir/annual-reports.

Laporan Tahunan Bank BRI (2015-2019). Terpublikasikan melalui website: https://bri.co.id/laporan.

Laporan Tahunan Bank BNI (2015-2019). Terpublikasikan melalui website: https://www.bni.co.id/id-id/perusahaan/hubunganinvestor/laporanpresentasi.

Laporan Tahunan Bank BCA (2015-2019). Terpublikasikan melalui website: https://www.bca.co.id/tentang-bca/hubungan-investor/laporan-tahunan

Laporan Tahunan Bank CIMB Niaga (2015-2019). Terpublikasikan melalui website: https://investor.cimbniaga.co.id

Laporan Tahunan Bank Danamon Indonesia (2015-2019). Terpublikasikan melalui website: https://www.danamon.co.id

Lasta, H. A., Arifin, Z., \& Nuzula, N. F. (2014). Analisis Tingkat Kesehatan Bank Dengan Menggunakan Pendekatan RGEC (Risk Profile, Good Corporate Governance, Earnings, Capital) (Studi pada PT Bank Rakyat Indonesia, Tbk Periode 2011-2013). Jurnal Administrasi Bisnis, 13(2), 1-10.

Nurhartanto. (2010). Pengaruh Rasio Camels Terhadap Harga Saham (Studi Empiris Pada Bank Yang Terdaftar DI BEI. Skripsi. Unversitas Diponegoro: Semarang.

Otoritas Jasa Keuangan. (2016). Peraturan Otoritas Jasa Keuangan Nomor 18/POJK.03/2016.

Praditasari, K.W. (2009). Analisis pengaruh tingkat kesehatan bank terhadap harga saham pada perusahaan perbankan yang go-public periode 2004-2008, Jurnal Fakultas Ekonomi Universitas Gunadarma.

Purwasih, R. (2010). Pengaruh Rasio CAMEL Terhadap Perubahan Harga Saham Perusahaan Perbankan yang Go Public di Bursa Efek Indonesia (BEI) Tahun 2006-2008. Skripsi. Fakultas Ekonomi Universitas Diponegoro, Semarang.

Ramadhany, A. P. (2015). Analisis Perbandingan Tingkat Kesehatan Bank Berdasarkan Risk Profile, Good Corporate Governance, Earnings dan Capital (RGEC) Pada Bank Konvensional BUMN dan Swasta (Studi pada Bank Umum Milik Negara dan Bank Swasta Nasional Devisa yang Terdaftar di Bursa Efek Indonesia Periode 2011-2013). Jurnal Administrasi Bisnis, 23(1), 1-9. 
Riyadi, S. (2014). Analisis Pengaruh Kinerja Keuangan, BI Rate dan Earning Per Share Terhadap Harga Saham Bank BUMN Di Bursa Efek Indonesia (Periode 2008-2013). Jurnal Ekonomi, Manajemen Dan Akuntansi, Vol.17, No.2 ISSN 1410-8224.

Riyadi, S. (2017). Manajemen Perbankan Indonesia. Jakarta: PT Raja Grafindo Persada.

Sari, A. P. (2018). Analisis Pengaruh Kinerja Keuangan Terhadap Tngkat Kesehatan Bank Syariah Dengan Menggunakan Metode RGEC Periode 2012-2016. Jurnal of Economics and Business, 2(1), 13-28.

Tjondro, D. \& R. Wilopo. (2011). Pengrauh Good Corporate Governance (GCG) Terhadap Profitabilitas dan Kinerja Saham Perusahaan Perbankan yang Tercatat di Bursa Efek Indonesia. Journal of Business an Banking, 1(1), 1-14. 